\title{
Listeria Species Occurrence and Associated Risk Factors and Antibiogram of Listeria Monocytogenes in Milk and Milk Products in Ambo, Holeta, and Bako Towns, Oromia Regional State, Ethiopia
}

\section{Bizunesh Mideksa Borena ( $\boldsymbol{\sigma}$ bizunesh.mideksa@ambou.edu.et )}

College of Agriculture and Veterinary Science, Ambo; University https://orcid.org/0000-0002-7531$769 X$

\section{Lemma Dilgasa}

Department of Veterinary Science, College of Agriculture and Veterinary Science, Ambo University Endrias Zewdu Gebremedhin

Department of Veterinary Science, College of Agriculture and Veterinary Science, Ambo University

\section{Edilu Jorga Sarba}

Department of Veterinary Science, College of Agriculture and Veterinary Science, Ambo University

\section{Lencho Megersa Marami}

Department of Veterinary Laboratory Technology, College of Agriculture and Veterinary Science, Ambo University

\section{Kebede Abdisa Kelbesa}

Department of Veterinary Science, College of Agriculture and Veterinary Science, Ambo University

\section{Nega Desalegn Tadese}

Department of Veterinary Laboratory Technology, College of Agriculture and Veterinary Science, Ambo University

\section{Research}

Keywords: Antimicrobial susceptibility, Ethiopia, Milk, Listeria species, Prevalence, Risk Factor

Posted Date: October 22nd, 2021

DOl: https://doi.org/10.21203/rs.3.rs-989141/v1

License: @ (i) This work is licensed under a Creative Commons Attribution 4.0 International License. Read Full License 
Version of Record: A version of this preprint was published at Veterinary Medicine International on April 14th, 2022. See the published version at https://doi.org/10.1155/2022/5643478. 


\section{Abstract \\ Background}

Listeriosis is a severe foodborne disease of significant burden to public health caused by consuming food contaminated with Listeria species. The current study was aimed to estimate the prevalence and associated risk factors of Listeria species and assess the antibiogram of Listeria monocytogenes ( $L$. monocytogenes) isolated from milk and milk products from Holeta, Ambo, and Bako towns, Ethiopia.

\section{Methods}

A cross sectional study was employed and a systematic random sampling method was used to collect raw milk and milk products samples. A total of 482 samples (384 milk, 35 cottage cheeses, 30 bulk tank milk, and 33 curdle milk) were collected and isolation and identification of Listeria species were done using standard microbiological techniques. Antimicrobial susceptibility test for $L$. monocytogenes was performed using the Kirby-Bauer disk diffusion technique. Descriptive statistics was used to summarize the prevalence of Listeria while Chi-square test and logistic regression were used to determine the association between the prevalence of Listeria and the risk factors and the magnitude of association, respectively

\section{Results}

The isolation rate of Listeria species was 7.67\% (37/482; $95 \%$ confidence interval (Cl):5.46, 10.42). The overall prevalence of L. monocytogenes was $2.28 \%$, (11/482; $95 \% \mathrm{Cl}: 1.14-4.04)$. The other species isolated were L. welshimeri 0.62\% (3/482; 95\% Cl:0.13 - 1.81), L. seeligeri 1.04\% (5/482; 95\% Cl:0.33 2.40), L. ivanovi 1.24\%, (6/482;95\% Cl:0.45 - 2.68) and L. grayi 2.49\% (12/482; 95\% Cl:5.46 - 10.42). Univariable logistic regression showed that study town, herd size, farm size, number of lactating cows, and management system were the factors significantly associated with for the isolation of Listeria species at farm level while intensive management system was independent predictor at cow level in the multivariable model (adjusted odds ratio $=3.38, \mathrm{P}=0.046$ ). L. monocytogenes isolates showed the highest resistance against oxacillin (100\%), amoxicillin (90.91\%), and vancomycine (81.82\%). L. monocytogenes showed very high multi-drug resistance (MDR) [81.82\%].

\section{Conclusion}

The current study showed widespread of Listeria species MDR Listeria monocytogenes isolates in cow raw milk and milk products from Ambo, Holeta, and Bako towns, Oromia Regional State, Ethiopia.

\section{Background}


Biological contamination of food is a global public health problem. Among animal-origin foods, cow's milk needs special attention because it is highly perishable and widely consumed by the population.

There is a trend to consume raw milk based on the idea that the heat destroys the nutritional and health benefits of milk and can cause detrimental effects [1]. On a worldwide basis, over 91 million people are sickened as a consequence of foodborne pathogens and associated illnesses. Foodborne pathogens and outbreaks of associated diseases occur frequently and pose significant constraints to consumer health in many parts of the world, resulting in morbidity, mortality, and economic losses [2]. Through food, more than $\mathbf{2 0 0}$ foodborne diseases are transmitted to humans. Listeriosis is one of the severe foodborne diseases caused by consuming food contaminated with Listeria monocytogenes [3]. It is associated with the consumption of contaminated milk, soft or semi-soft cheese, undercooked and ready-to-eat foods, unwashed raw vegetables, and fruits [4].

The safety of dairy products concerning foodborne diseases in developing countries is of great issue. This is due to the poor practices and the production of milk and milk products under unhygienic conditions [5]. Raw milk may be a risk for public health if contaminated with zoonotic pathogens, which are often part of the intestinal flora or present on the udder of healthy dairy animals and can easily contaminate the environment and the milk during the production process [6]. Three factors play a fundamental role in food poisoning outbreaks concerning food handlers: knowledge, attitude, and practice [7].

Previous studies conducted in different parts of Ethiopia showed different prevalence values and drug resistance profiles of Listeria from milk and milk products. Accordingly, Listeria species were reported from raw milk in Selale (22\%) by Gebretsadik et al. [8] and in Jimma town by Muhammed et al. [9]. In addition, Derra et al. [10] showed the prevalence of Listeria from raw milk $8.5 \%$, cottage cheese $6.8 \%$, and cream-cake samples $22.0 \%$, and a low level of occurrence of antimicrobial-resistant $L$. monocytogenes isolates from Addis Ababa. L. monocytogenes has also been reported in several milk processing environments at various stages of production [11], leading to higher chances of cross-contamination of the finished products [12]. Garedew et al. [13] from Gondar town reported Listeria species prevalence of $25 \%$ in food samples including unpasteurized milk. The same authors also detected multi-drug resistant L. monocytogenes. Another study conducted in the central highlands of Ethiopia showed a $28.4 \%$ overall prevalence of Listeria spp and 5.6\% L. monocytogenes in raw milk and milk products [14].

Pathogenic Listeria species load reduction regulations encouragement, the teaching of food safety awareness concerning food trade and food handlers, increasing listeriosis awareness concerning health impact, usual disease follows up and early investigations of the reported diseases are some of the efficient strategies to control listeriosis $[10,15,16]$. Specifically, pregnant women are advised not to consume unpasteurized milk, unpasteurized cheeses, and other foods with Listeria species contamination potential [17]. In addition, the excessive use of antimicrobials has led to antibiotic resistance and even multi-resistance. The antibiotic resistance of Listeria species has undoubtedly made the treatment of listeriosis complex. In the current study areas, information on the occurrence, antimicrobial profile, and distribution of L. monocytogenes and other Listeria species is very limited, 
although foods of animal origin including milk and milk products are consumed well like any other part of Ethiopia. The aims of this study were, therefore, to estimate the prevalence and risk factors of Listeria species and determine antibiogram of $L$. monocytogenes isolated from raw cattle milk and milk products in Ambo, Holeta, and Bako towns, Oromia Regional State, Ethiopia.

\section{Methods}

\section{Study Area}

The study was conducted in three selected towns (Ambo, Holeta, and Bako) of Oromia Regional State, Ethiopia. Ambo town is the administrative center of West Shewa Zone, which is located $114 \mathrm{~km}$ West of Addis Ababa at the latitude of $8^{\circ} 59^{\prime} \mathrm{N} 37^{\circ} 51^{\prime} \mathrm{E}$ and longitude of $8.983^{\circ} \mathrm{N} 37.85^{\circ} \mathrm{E}$. The elevation of Ambo town ranges from 1900 to 2275 meters above sea level (m.a.s.l.). The temperature in the town ranges from $19^{\circ} \mathrm{C}$ to $29^{\circ} \mathrm{C}$ with an average annual temperature and rainfall of $22^{\circ} \mathrm{C}$ and $900 \mathrm{~mm}$, respectively. Ambo town has a total human population of 74,843 out of which 39,192 are males and 35,651 are female [18]. There were 8 registered dairy farms and many smallholder farms in the towns. The total herd size per farm ranged from $3-65$ animals. The number of lactating cows per farm ranged from $2-32$ [19].

Holeta is located in Finfine special Zone $44 \mathrm{Kms}$ West of Addis Ababa with a latitude and a longitude of

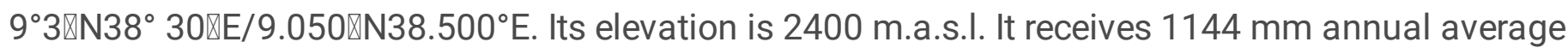
precipitation, with average minimum and maximum temperatures of $6^{\circ} \mathrm{C}$ and $22^{\circ} \mathrm{C}$, respectively. The total human population of Holeta town is 25,593 , of whom12,605, are men and 12, 988 women [18]. There are 20 registered and many smallholders dairy farms in the towns. The herd size per farm ranges from 5 300 animals. The lactating cows per farm range from 2-140 [20].

Bako town, the capital of Bako Tibe district, is located in the West Shewa Zone of Oromia Regional State. Bako is located $260 \mathrm{~km}$ West of Addis Ababa with longitude and latitude of lies between $9.1274^{\circ} \mathrm{N}$ and $37.0561^{\circ} \mathrm{E} .9^{\circ} 08^{\prime} \mathrm{N} 37^{\circ} 03^{\prime} \mathrm{E}$, respectively. It has an elevation ranging from $1300-2998 \mathrm{~m}$.a.s.l, average rainfall of $886.5 \mathrm{~mm}$, and an average temperature of $21.2^{\circ} \mathrm{C}$. The town has a total human population of 35,769 out of which 16,692 are male and 19,077 are females [18]. There are five registered dairy farms in the towns. The total herd size per farm ranges from 7 - 315 animals. The lactating cows per farm range from 2-152 [21].

\section{Study population}

All lactating dairy cows found in the study areas were considered as the study population in this study.

\section{Study design}

A cross-sectional study was conducted from September 2018 to June 2019 in Ambo, Holeta, and Bako towns to estimate the prevalence and associated risk factors of Listeria species and the antimicrobial susceptibility profile of $L$. monocytogenes isolated from raw cattle milk and milk products in the study areas. 


\section{Sample size determination}

The sample size was calculated based on the formula given by Thrusfield [22] considering $50 \%$ expected prevalence and $95 \%$ confidence interval and $5 \%$ level of precision. The total sample size using the formula given here below was 384 .

$$
\mathrm{N}=\frac{1.96^{2} P \exp (1-P \exp )}{d^{2}}
$$

Where $\mathrm{N}$ = required sample size, $\mathrm{p}=$ expected prevalence, and $\mathrm{d}=$ desired absolute precision. This sample size was distributed proportionally to the three towns based on lactating cows' population. Accordingly, 127 lactating cows from Ambo, 190 from Holeta, and 67 from Bako were considered for this study. In addition, a total of 98 samples consisting of bulk tank milk (30), curdle milk "ergo"- naturally fermented curdled milk of a cow (33) and cottage cheese (35) were randomly sampled.

\section{Sample collection}

After identifying dairy farms and milk product selling shops and markets in the study areas, a systematic random sampling method was used to collect raw milk $(\mathrm{N}=384)$ and milk products $(\mathrm{N}=98)$ were collected. The raw milk and milk products were collected aseptically in sterile plastic containers (slider freezer bags, oxo-biodegradable, China). The collected samples were identified by date of collection, breed, and age of the cow and each sample was given a code number. All milk samples were transported immediately by using an icebox containing ice pack to Ambo University Food safety and zoonoses research laboratory and stored at $4^{0} \mathrm{C}$ until analyzed.

\section{Study methodology}

\section{Questionnaire survey}

A questionnaire survey consisting of close-ended questions was developed and administered for dairy farm workers of Ambo, Holeta, and Bako towns to assess potential risk factors for milk and milk products contamination by Listeria species. From each sample source, one or more member(s) of the household or farm workers who were responsible for milk and dairy product handling were identified and requested to respond to the set of questions. The potential risk factors considered for contamination were age of cows (2 -4, $5-7,8-15$ years), breed (local, cross, Jersey), parity (first, second, third, fourth), management (extensive, semi-intensive, intensive), season (wet, dry), level of education of workers (college/university, secondary, primary, illiterate), farm hygiene (poor-bad smell and gross filth, moderate-some dirt visible, good- regularly cleaned and dry), herd size (small $\leq 10$, medium $11-50$, large $\geq 50$ ), number of lactating cows $(\leq 5,6-13, \geq 14)$, farm size (small, large), food safety information (yes, no), training on food safety (yes, no), washing hands before milking (yes, no), washing cow's udder before milking (yes, no), materials used for udder drying (collective towel, individual towel, just with hand/no towel), source of water for cleaning udder /utensils (pipe, river), washing hands before milking (yes, no), washing udder before milking (yes, no), type of container used to handle milk and milk products (plastic, stainless steel), gender 
of milk and milk product handler (female, male) and time of udder washing (before milking, no washing, before and after milking).

\section{Isolation and identification of Listeria species}

Raw milk or milk products sample of $25 \mathrm{ml}$ or $\mathrm{g}$ was measured and agitated thoroughly until the contents became homogeneous. The homogenized samples were then aseptically transferred into flasks containing $225 \mathrm{ml}$ of previously prepared half Fraser (Oxoid, UK) for the sake of repairing Listeria species damaged during transportation. The samples were incubated at $30{ }^{\circ} \mathrm{C}$ for 24 hours, then after, $0.1 \mathrm{ml}$ of the homogenate was taken and inoculated into $10 \mathrm{ml}$ of secondary Fraser broth (Oxoid, UK) and incubated for 24 hours at $37^{\circ} \mathrm{C}$. After 24 hours of incubation, $0.1 \mathrm{ml}$ of a positive culture from secondary Fraser broth medium with black/dark brown color, dark green color change were taken and streaked onto Oxford agar (OXA) (Oxoid, UK) plates containing manufacturer's supplements and the plates were incubated at $37^{\circ} \mathrm{C}$ for $24-48$ hours. After incubation, the growth of Listeria species on the Oxford agar plate was examined for black halo colonies typical of Listeria species. Colonies formed by Listeria species are characterized by a brownish sunken center appearance surrounded by a black-halo formation as a result of aesculin hydrolysis. Presumptive Listeria colonies were sub-cultured on TSAYE (Trypticase Soy Agar with $0.6 \%$ Yeast Extract) (Oxoid, UK) incubated for $24 \pm 2$ hours at $30^{\circ} \mathrm{C}$ and further characterized. Typical colonies from TSAYE (1 $\mathrm{mm}$ to $2 \mathrm{~mm}$ in diameter, convex, colorless, and opaque) were subjected to characterization including Gram staining, motility test, catalase test, hemolysis, carbohydrate utilization, and Christe, Atkins, and Munch-Peterson (CAMP) tests [23, 24]. The Listeria species were assumed to be gram-positive, Cocco-bacillary or short rod-shaped, catalase test positive that forms gas bubbles and umbrella-shaped growth pattern [25].

\section{Antimicrobial susceptibility test}

Kirby Bauer disc diffusion method was used for antimicrobial susceptibility testing as per the standard procedure recommended by the Clinical and Laboratory Standards Institute [26]. Antimicrobial susceptibility testing was done for only L. monocytogenes due to the limitation of antimicrobial discs. The L. monocytogenes isolates were subjected to an antimicrobial susceptibility test against 12 commercially available antimicrobial discs (Oxoid, UK) selected based on common usage. The antimicrobial discs selected were amoxicillin $(10 \mu \mathrm{g})$, cefotaxime $(30 \mu \mathrm{g})$, chloramphenicol $(30 \mu \mathrm{g})$, gentamicin $(10 \mu \mathrm{g})$, nitrofurantoin $(300 \mu \mathrm{g})$, azithromycin $(15 \mu \mathrm{g})$, tetracycline $(30 \mu \mathrm{g})$, ampicillin $(10 \mu \mathrm{g})$, vancomycin $(10 \mu \mathrm{g})$, nalidixic acid $(30 \mu \mathrm{g})$, oxacillin $(1 \mu \mathrm{g})$ and norfloxacin $(10 \mu \mathrm{g})$. Briefly, an inoculum from a cell suspension of approximately $10^{6} \mathrm{cells} / \mathrm{ml}$ was used for the test. The cells suspension was prepared by inoculating sterile normal saline with a pure culture of the test organisms and incubating for 4 hours. Following this, the cell suspension turbidity was attuned to equal $0.5 \mathrm{McF}$ arland Standard. To confirm the matching, the turbidity was also read through a spectrophotometer at $625 \mathrm{~nm}$ before inoculation. Two to three colonies of the isolates to be tested from TSAYE were inoculated into the Muller Hinton broth and incubated for 24 hours at $37^{\circ} \mathrm{C}$. Then, a swab was taken from each bacterial suspension by sterile cotton swab and then spread on the Muller Hinton agar. According to the standard 
procedure, the discs were firmly placed in the interval of $3 \mathrm{~cm}$ spacing from each other onto the medium with sterile forceps and incubation at $37^{\circ} \mathrm{C}$ for 24 hours [27]. The diameters of clear zones around the discs were measured against a black background using a ruler and compared with standards given by CLSI [26]. L. monocytogenes ATCC7644, E. coli ATCC25922, and S. aureus ATCC6538 reference strains were used as quality control.

\section{Data management and statistical analysis}

The data generated from laboratory tests and questionnaire surveys were entered into a Microsoft Excel spreadsheet (Microsoft Corporation), transferred, and analyzed using STATA version 14.0 software (Stata Crop. College Station, USA). Descriptive statistics was used to summarize the data. The prevalence of Listeria species was calculated by dividing the number of positive samples by the total number of tested samples and multiplied by 100 . Similarly, the prevalence of antimicrobial-resistant $L$. monocytogenes was calculated by dividing the number of resistant isolates by the total number of tested isolates and multiplied by 100 . Chi-square test and logistic regression were used to assess the association of risk factors with the prevalence of Listeria species. Dummy variables were created for those explanatory variables with more than two categories. For all risk factors, the level with the lowest prevalence was used as a reference category. Those variables with a p-value of less than 0.25 in the univariable analysis were further analyzed by multivariable logistic regression after checking for confounders. In all tested cases, $95 \%$ confidence intervals and $p<0.05$ were set for significance.

\section{Results}

\section{Prevalence and identification of Listeria species}

Out of 482 samples tested, 37 (7.67\%; 95\%: Cl: $5.46,10.42)$ were found to be positive for the Listeria species. The prevalence of Listeria species in Ambo town (10.98\%) was the highest when compared to Holeta (6.89\%) and Bako 3(3.90\%) towns (Table 1).

Table 1 The overall prevalence of Listeria species isolated from dairy cow milk and milk products in study towns 


\begin{tabular}{|c|c|c|c|c|}
\hline \multirow[t]{2}{*}{ Study areas } & \multirow[t]{2}{*}{ Sample type } & \multicolumn{3}{|l|}{ Listeria species } \\
\hline & & Number tested & Prevalence (\%) & $95 \% \mathrm{Cl}$ \\
\hline \multirow[t]{5}{*}{ Ambo } & Cow milk & 127 & $14(11.02)$ & $1.59-4.82$ \\
\hline & Curdle milk & 10 & $1(10.00)$ & $0.00-1.15$ \\
\hline & Bulk tank milk & 17 & $3(17.65)$ & $0.12-1.80$ \\
\hline & Cottage cheese & 10 & $0(0.00)$ & $0.00-1.15$ \\
\hline & Subtotal & 164 & 18 (10.98) & $2.22-5.83$ \\
\hline \multirow[t]{5}{*}{ Holeta } & Cow milk & 190 & $12(6.32)$ & $1.29-4.30$ \\
\hline & Curdle milk & 15 & $1(6.67)$ & $0.00-1.15$ \\
\hline & Bulk tank milk & 7 & $1(14.29)$ & $0.00-1.15$ \\
\hline & Cottage cheese & 20 & $2(10.00)$ & $0.00-1.49$ \\
\hline & Subtotal & 232 & $16(6.90)$ & $1.90-5.33$ \\
\hline \multirow[t]{5}{*}{ Bako } & Cow milk & 67 & $1(1.49)$ & $0.00-1.15$ \\
\hline & Curdle milk & 5 & $0(0.00)$ & \\
\hline & Bulk tank milk & 9 & $1(11.11)$ & $0.00-1.15$ \\
\hline & Cottage cheese & 5 & $1(20.00)$ & $0.00-1.15$ \\
\hline & Subtotal & 86 & $3(3.49)$ & $0.12-1.80$ \\
\hline Overall & & 482 & $37(7.68)$ & $5.46-10.42$ \\
\hline
\end{tabular}

$\mathrm{Cl}$, Confidence Interval

The highest prevalence of Listeria species (15.15\%; 95\% Cl: 5.11-31.90) and L. monocytogenes (9.09; 95\% Cl: 1.92-24.33) was detected in bulk tank milk. Similarly, the lowest prevalence of Listeria species (6.67\%; $95 \% \mathrm{Cl}: 0.82-22.07)$ and L. monocytogenes $(0.00 ; 95 \% \mathrm{Cl}: 0.00-1.15)$ was found in curdling milk (Table 2). The overall prevalence of Listeria species from milk and milk products was $7.68 \%$ (37/482) and from which, the highest prevalence was recorded for Listeria grayi $(2.49 \%)$ and the lowest for $L$. weshimeri $(0.62 \%)$. The prevalence of $L$. monocytogenes, $L$. ivanovii, and $L$. seeligeri was $2.28 \%, 1.24 \%$, and $1.04 \%$ respectively.

Table 2 Comparison of prevalence of Listeria species from different samples 


\begin{tabular}{|c|c|c|c|c|c|}
\hline \multirow[t]{2}{*}{ Sample type } & \multirow{2}{*}{$\begin{array}{l}\text { No. } \\
\text { tested }\end{array}$} & \multicolumn{2}{|c|}{ Listeria species } & \multicolumn{2}{|c|}{ L. monocytogenes } \\
\hline & & $\begin{array}{l}\text { No. } \\
\text { Pos. }\end{array}$ & $\begin{array}{l}\% \text { Prevalence (95\% } \\
\mathrm{Cl})\end{array}$ & $\begin{array}{l}\text { No. } \\
\text { Pos. }\end{array}$ & $\begin{array}{l}\% \text { Prevalence }(95 \% \\
\mathrm{Cl})\end{array}$ \\
\hline Bulk tank milk & 33 & 5 & $15.15(5.11-31.90)$ & 3 & 9.09 (1.92-24.33) \\
\hline Cottage Cheese & 35 & 3 & $8.57(1.80-23.06)$ & 1 & $2.85(0.00-1.15)$ \\
\hline $\begin{array}{l}\text { Cow level raw } \\
\text { milk }\end{array}$ & 384 & 27 & 7.03 (4.68-10.07) & 7 & $1.82(0.58-2.96)$ \\
\hline Curdle milk & 30 & 2 & $6.67(0.82-22.07)$ & 0 & $0.00(0.00-1.15)$ \\
\hline Total & 482 & 37 & $9.64(6.88-13.04)$ & 11 & $2.28(1.14-4.04)$ \\
\hline
\end{tabular}

$\mathrm{Cl}$, Confidence Interval; No., number; pos, sample positive for L. monocytogenes

\section{Risk factor analyses}

The farm-level prevalence of Listeria species was significantly high $(p<0.05)$ in Holeta $(63.64 \%)$ than Bako $(18.75 \%)$ town, in large herd size $(85.71 \%)$ than smallholder $(12.50 \%)$, in large farms $(58.33 \%)$ than small farms $(12.50 \%)$, and in intensively $(50.00 \%)$ than extensively $(8.33 \%)$ managed cows (Table 3$)$. The following independent variables have univariable p-values less than 0.25 hence are potential variables for inclusion into the multivariable model: town, management, farm hygiene, education level, herd size, number of lactating cows, farm size, time of udder washing, materials used for udder drying, and source of water for udder and hand washing. Among these variables, the multicollinearity matrix showed that the following are collinear. Management vs town $(r=0.69)$, education vs management $(r=0.51)$, number of lactating cow's vs farm hygiene ( $r=0.58)$, number of lactating cow's vs herd size ( $r=0.91)$, farm size vs herd size $(r=0.90)$, and farm size vs number of lactating cows $(r=0.83)$. Among the collinear variables management, farm hygiene, and herd size were selected for inclusion into the multivariable model due to biological plausibility. Moreover, the time of udder washing, materials used for udder drying, and source of water for udder and utensil washing were also included in the multivariable model (Table 3). Finally, after running the full model, herd size was removed from the model due to confounding identified through the change in $\mathrm{OR}>30 \%$ between univariable and multivariable models.[28] The Hosmer-Lemeshow goodness of fit test revealed that the model predicts or fitted the data well $\left(H L X^{2}=5.06 ; p=0.7511\right.$, sensitivity $=35.3 \%$, specificity $=83.9 \%$, positive predicting value $54.6 \%$, negative predicting value $=70.3 \%$, ROC $=0.7581$ ). However, none of the variables were independent and significant predictors of Listeria species isolation rate.

Table 3 Results of logistic regression analysis of farm-level potential risk factors for isolation of Listeria species

Univariable logistic regression analysis of animal level risk factors showed that the risk of contamination 


\begin{tabular}{|c|c|c|c|c|c|c|c|}
\hline \multirow[t]{2}{*}{ Risk factors } & \multirow[t]{2}{*}{ Categories } & \multirow{2}{*}{$\begin{array}{l}\text { No. } \\
\text { tested }\end{array}$} & \multirow{2}{*}{$\begin{array}{l}\text { No. } \\
\text { positive } \\
(\%)\end{array}$} & \multicolumn{2}{|c|}{ Univariable } & \multicolumn{2}{|c|}{ Multivariable } \\
\hline & & & & $\begin{array}{l}\mathrm{OR}(95 \% \\
\mathrm{Cl})\end{array}$ & $\begin{array}{l}\text { P- } \\
\text { value }\end{array}$ & $\begin{array}{l}\text { OR } \\
(95 \% \\
\mathrm{Cl})\end{array}$ & $\begin{array}{l}\mathrm{P} \text { - } \\
\text { value }\end{array}$ \\
\hline \multirow[t]{3}{*}{ Town } & Bako & 16 & $3(18.75)$ & 1.0 & - & & \\
\hline & Ambo & 21 & 7 (33.33) & $\begin{array}{l}2.17 \\
(0.46- \\
10.20)\end{array}$ & 0.328 & & \\
\hline & Holeta & 11 & $7(63.64)$ & $\begin{array}{l}7.58 \\
(1.31- \\
43.92)\end{array}$ & 0.024 & & \\
\hline \multirow[t]{3}{*}{ Farm hygiene } & Poor & 23 & $6(26.09)$ & 1.0 & & 1.0 & - \\
\hline & Good & 13 & $5(38.46)$ & $\begin{array}{l}1.77 \\
(0.41- \\
7.58)\end{array}$ & 0.441 & $\begin{array}{l}1.69 \\
(0.27- \\
10.46)\end{array}$ & 0.570 \\
\hline & Moderate & 12 & $6(50.0)$ & $\begin{array}{l}2.83 \\
(0.65- \\
12.26)\end{array}$ & 0.164 & $\begin{array}{l}3.53 \\
(0.51- \\
24.59)\end{array}$ & 0.203 \\
\hline \multirow[t]{4}{*}{$\begin{array}{l}\text { Level of education } \\
\text { of workers }\end{array}$} & $\begin{array}{l}\text { College and } \\
\text { above }\end{array}$ & 14 & $4(28.27)$ & 1.0 & & & \\
\hline & Secondary & 13 & $4(30.77)$ & $\begin{array}{l}1.11 \\
(0.21- \\
5.80)\end{array}$ & 0.901 & & \\
\hline & Elementary & 15 & 5 (33.33) & $\begin{array}{l}1.25 \\
(0.26- \\
6.07)\end{array}$ & 0.782 & & \\
\hline & Illiterate & 6 & $4(66.67)$ & $\begin{array}{l}5.0 \\
(0.64- \\
39.06)\end{array}$ & 0.125 & & \\
\hline \multirow[t]{3}{*}{ Herd size } & $\begin{array}{l}\text { Smallholder } \\
(\leq 10)\end{array}$ & 24 & $3(12.50)$ & 1.0 & - & & \\
\hline & $\begin{array}{l}\text { Medium (10 - } \\
50)\end{array}$ & 17 & $8(47.06)$ & $\begin{array}{l}6.22 \\
(1.33- \\
29.01)\end{array}$ & 0.020 & & \\
\hline & Large $(\geq 50)$ & 7 & $6(85.71)$ & $\begin{array}{l}42(3.67- \\
481.03)\end{array}$ & 0.003 & & \\
\hline \multirow[t]{2}{*}{ Farm size } & Small & 24 & $3(12.50)$ & 1.0 & - & & \\
\hline & Large & 24 & $\begin{array}{l}14 \\
(58.33)\end{array}$ & $\begin{array}{l}9.8 \\
(2.28- \\
42.06)\end{array}$ & 0.002 & & \\
\hline No. of lactating & $\leq 5$ & 21 & $2(9.52)$ & 1.0 & - & & \\
\hline
\end{tabular}




\begin{tabular}{|c|c|c|c|c|c|c|c|}
\hline \multirow[t]{2}{*}{ cows } & $6-13$ & 18 & $8(44.44)$ & $\begin{array}{l}7.6 \\
(1.35- \\
42.80)\end{array}$ & 0.021 & & \\
\hline & $\geq 14$ & 9 & 7 (77.78) & $\begin{array}{l}33.25 \\
(3.90- \\
283.45)\end{array}$ & 0.001 & & \\
\hline \multirow{3}{*}{$\begin{array}{l}\text { Management } \\
\text { system }\end{array}$} & Extensive & 12 & $1(8.33)$ & 1.0 & & 1.0 & - \\
\hline & Semi-intensive & 14 & $5(35.71)$ & $\begin{array}{l}6.11 \\
(0.60- \\
62.23)\end{array}$ & 0.126 & $\begin{array}{l}2.93 \\
(0.18- \\
48.45)\end{array}$ & 0.452 \\
\hline & Intensive & 22 & $11(50.00)$ & $\begin{array}{l}11(1.21- \\
100.39)\end{array}$ & 0.034 & $\begin{array}{l}6.38 \\
(0.54- \\
75.95)\end{array}$ & 0.143 \\
\hline \multirow{2}{*}{$\begin{array}{l}\text { Training } \\
\text { on food safety }\end{array}$} & Yes & 23 & 8(34.78) & 1.0 & & & \\
\hline & No & 25 & $9(36.00)$ & $\begin{array}{l}1.05 \\
(0.32- \\
3.45)\end{array}$ & 0.930 & & \\
\hline Washing cows & No & 7 & $2(28.58)$ & 1.0 & - & & \\
\hline $\begin{array}{l}\text { Udder before } \\
\text { milking }\end{array}$ & Yes & 41 & 15(36.59) & $\begin{array}{l}1.44 \\
(0.25- \\
8.37)\end{array}$ & 0.683 & & \\
\hline \multirow[t]{3}{*}{$\begin{array}{l}\text { Materials used for } \\
\text { udder drying }\end{array}$} & $\begin{array}{l}\text { Collective } \\
\text { towel }\end{array}$ & 13 & $2(15.38)$ & 1.0 & - & 1.0 & - \\
\hline & $\begin{array}{l}\text { Without } \\
\text { towel/just } \\
\text { with hand }\end{array}$ & 10 & $4(40.00)$ & $\begin{array}{l}3.67 \\
(0.51- \\
26.22)\end{array}$ & 0.196 & $\begin{array}{l}3.72 \\
(0.26- \\
53.45)\end{array}$ & 0.333 \\
\hline & $\begin{array}{l}\text { Individual } \\
\text { towel }\end{array}$ & 25 & 11(44.00) & $\begin{array}{l}4.32 \\
(0.79- \\
23.68)\end{array}$ & 0.092 & $\begin{array}{l}2.52 \\
(0.31- \\
20.52)\end{array}$ & 0.388 \\
\hline \multirow{2}{*}{$\begin{array}{l}\text { Source of water for } \\
\text { Udder and utensil } \\
\text { washing }\end{array}$} & River & 12 & $2(16.67)$ & 1.0 & - & 1.0 & - \\
\hline & Pipe & 36 & 15(41.67) & $\begin{array}{l}3.57 \\
(0.68- \\
18.72)\end{array}$ & 0.132 & $\begin{array}{l}1.53 \\
(0.21- \\
11.11)\end{array}$ & 0.672 \\
\hline \multirow{2}{*}{$\begin{array}{l}\text { Washing hands } \\
\text { before milking }\end{array}$} & Yes & 30 & 10(33.33) & 1.0 & - & & \\
\hline & No & 18 & $7(38.89)$ & $\begin{array}{l}1.27 \\
(0.38- \\
4.29)\end{array}$ & 0.697 & & \\
\hline \multirow{2}{*}{$\begin{array}{l}\text { timetimeTTime } \\
\text { Time of udder } \\
\text { washing }\end{array}$} & Before milking & 25 & $7(28.00)$ & 1.0 & - & 1.0 & - \\
\hline & No washing & 6 & 2 (33.33) & $\begin{array}{l}1.29 \\
(0.19- \\
8.67)\end{array}$ & 0.796 & $\begin{array}{l}1.54 \\
(0.16- \\
14.73)\end{array}$ & 0.710 \\
\hline
\end{tabular}




$\begin{array}{lllllll}\text { Before and } & 17 & 8(47.06) & 2.29 & 0.210 & 2.29 & \\ \text { after milking } & & & (0.63- & & (0.46- & 0.314 \\ & & & 8.32) & & 11.53) & \\ & & & & \end{array}$

of raw milk by Listeria species was 8.12 times higher in Ambo as compared to Bako town ( $\mathrm{p}=0.045)$. Similarly, the likelihood of contamination of milk by Listeria species was 2.82 times higher in intensively managed cows as compared to extensively managed cows $(p=0.031)$. Independent variables like the season, breed, age, parity, washing hands before milking, washing udder before milking, materials used for udder drying, and source of water for udder/hand washing were not significantly associated with the isolation of Listeria species from raw cow milk $(p>0.05)$. None of the independent variables studied were collinear with each other $(/ \mathrm{r}<0.5 /)$.

Independent variables with univariable $\mathrm{p}<0.25$ considered for the multivariable model include town, season, breed, management system, materials used for udder drying, and source of water used for udder/hand washing. The final multivariable logistic regression model revealed that the management system is an independent predictor of Listeria species isolation from milk (Table 4).

Table 4 Logistic regression analyses of potential risk factors for Listeria species isolation rate in study towns at cow level 


\begin{tabular}{|c|c|c|c|c|c|}
\hline \multirow[t]{2}{*}{ Risk factors } & \multirow[t]{2}{*}{ Category } & \multicolumn{2}{|l|}{ Univariable } & \multicolumn{2}{|c|}{ Multivariable } \\
\hline & & OR $(95 \% \mathrm{Cl})$ & $\begin{array}{l}\mathrm{P}- \\
\text { value }\end{array}$ & $\begin{array}{l}\text { OR } \\
(95 \% \mathrm{Cl})\end{array}$ & $\begin{array}{l}\mathrm{P} \text { - } \\
\text { value }\end{array}$ \\
\hline \multirow[t]{3}{*}{ Town } & Bako & 1.0 & - & 1.0 & - \\
\hline & Holeta & $\begin{array}{l}4.45(0.57- \\
34.89)\end{array}$ & 0.155 & $\begin{array}{l}3.42(0.39- \\
29.97\end{array}$ & 0.267 \\
\hline & Ambo & $\begin{array}{l}8.18(1.05- \\
63.60)\end{array}$ & 0.045 & $\begin{array}{l}5.87(0.71- \\
48.32)\end{array}$ & 0.100 \\
\hline \multirow[t]{3}{*}{ Breed } & Local & 1.0 & - & 1.0 & - \\
\hline & Cross & $\begin{array}{l}2.57(0.58- \\
11.23)\end{array}$ & 0.209 & $\begin{array}{l}1.73(0.33- \\
9.01)\end{array}$ & 0.513 \\
\hline & Jersey & $\begin{array}{l}2.61(0.42- \\
16.41)\end{array}$ & 0.305 & $\begin{array}{l}2.64(0.39- \\
17.99)\end{array}$ & 0.323 \\
\hline \multirow[t]{3}{*}{ Age in years } & $2-4$ & 1.0 & - & & \\
\hline & $5-7$ & $\begin{array}{l}1.46(0.55 \\
-3.87)\end{array}$ & 0.448 & & \\
\hline & $8-15$ & $\begin{array}{l}1.69(0.52 \\
-5.45)\end{array}$ & 0.382 & & \\
\hline \multirow[t]{2}{*}{ Seasons } & Wet & 1.0 & - & 1.0 & - \\
\hline & Dry & $\begin{array}{l}1.68(0.72- \\
3.94)\end{array}$ & 0.232 & $\begin{array}{l}1.04(0.30- \\
3.63)\end{array}$ & 0.951 \\
\hline \multirow[t]{3}{*}{ Management system } & Extensive & - & - & 1.0 & \\
\hline & Semi-intensive & $\begin{array}{l}1.03(0.34- \\
3.19)\end{array}$ & 0.943 & $\begin{array}{l}1.38(0.37 \\
-5.20)\end{array}$ & 0.635 \\
\hline & Intensive & $\begin{array}{l}2.82(1.10- \\
7.24)\end{array}$ & 0.031 & $\begin{array}{l}3.38(1.02 \\
-11.18)\end{array}$ & 0.046 \\
\hline \multirow[t]{4}{*}{ Parity } & Second & 1.0 & - & & \\
\hline & Fourth & $\begin{array}{l}1.09(0.32 \\
-3.69)\end{array}$ & 0.895 & & \\
\hline & First & $\begin{array}{l}1.38(0.49 \\
-3.84)\end{array}$ & 0.544 & & \\
\hline & Third & $\begin{array}{l}1.65(0.48 \\
-5.67)\end{array}$ & 0.427 & & \\
\hline \multirow[t]{2}{*}{ Washing hands before milking } & Yes & 1.0 & - & & \\
\hline & No & $\begin{array}{l}1.37(0.63- \\
3.00)\end{array}$ & 0.429 & & \\
\hline
\end{tabular}




\begin{tabular}{|c|c|c|c|c|c|}
\hline \multirow[t]{2}{*}{ Washing udder before milking } & Yes & 1.0 & \multicolumn{3}{|l|}{-} \\
\hline & No & $\begin{array}{l}1.25(0.45 \\
-3.44)\end{array}$ & 0.668 & & \\
\hline \multirow[t]{3}{*}{ Materials used for udder drying } & $\begin{array}{l}\text { Collective/shared/ } \\
\text { towel }\end{array}$ & 1.0 & - & 1.0 & - \\
\hline & Individual towel & $\begin{array}{l}1.36(0.57 \\
-3.23)\end{array}$ & 0.493 & $\begin{array}{l}1.47(0.52 \\
-4.11)\end{array}$ & \\
\hline & $\begin{array}{l}\text { Just with hand/no } \\
\text { towel }\end{array}$ & $\begin{array}{l}2.45(0.81 \\
-7.40)\end{array}$ & 0.112 & $\begin{array}{l}2.35(0.63 \\
-8.71)\end{array}$ & 0.203 \\
\hline \multirow{2}{*}{$\begin{array}{l}\text { Source of water used for } \\
\text { udder/utensil washing }\end{array}$} & River & 1.0 & - & 1.0 & - \\
\hline & Tap & $\begin{array}{l}2.09(0.61 \\
-7.14)\end{array}$ & 0.238 & $\begin{array}{l}1.70(0.45 \\
-6.41)\end{array}$ & 0.436 \\
\hline
\end{tabular}

Chi-square analysis of the association between potential risk factors and prevalence of Listeria species in bulk tank milk, curdled milk, and cottage cheese revealed that none of the factors considered were significantly associated ( $p>0.05)$ (Table 5).

Table 5 Results of Chi-square analysis of the association between the prevalence of Listeria species in bulk tank milk, curdled milk, and cottage cheese and potential risk factors for contamination 


\begin{tabular}{|c|c|c|c|c|c|c|}
\hline Variable & Categories & $\begin{array}{l}\text { No. } \\
\text { tested }\end{array}$ & $\begin{array}{l}\text { No. } \\
\text { positive }\end{array}$ & $\begin{array}{l}\text { Prevalence } \\
(\%)\end{array}$ & $\begin{array}{l}\text { Chi- } \\
\text { square }\end{array}$ & $\begin{array}{l}\mathrm{P} \text { - } \\
\text { value }\end{array}$ \\
\hline \multirow[t]{3}{*}{ Town } & Holeta & 42 & 4 & 9.52 & 0.0382 & 0.981 \\
\hline & Bako & 19 & 2 & 10.53 & & \\
\hline & Ambo & 37 & 4 & 10.81 & & \\
\hline \multirow[t]{3}{*}{ Sample type } & Curdle milk & 30 & 2 & 6.67 & 1.3931 & 0.498 \\
\hline & $\begin{array}{l}\text { Cottage } \\
\text { cheese }\end{array}$ & 35 & 3 & 8.57 & & \\
\hline & $\begin{array}{l}\text { Bulk tank } \\
\text { milk }\end{array}$ & 33 & 5 & 15.15 & & \\
\hline \multirow[t]{2}{*}{ Gender of handler } & Female & 66 & 6 & 9.09 & 0.2733 & 0.601 \\
\hline & Male & 32 & 4 & 12.50 & & \\
\hline \multirow[t]{4}{*}{ Level of Education } & Primary & 23 & 1 & 4.35 & 1.2869 & 0.732 \\
\hline & Illiterate & 44 & 5 & 11.36 & & \\
\hline & Secondary & 25 & 3 & 12.00 & & \\
\hline & $\begin{array}{l}\text { College and } \\
\text { above }\end{array}$ & 6 & 1 & 16.67 & & \\
\hline \multirow[t]{2}{*}{ Food safety information } & No & 32 & 3 & 9.38 & 0.0356 & 0.850 \\
\hline & Yes & 66 & 7 & 10.61 & & \\
\hline \multirow{2}{*}{$\begin{array}{l}\text { Received training on food } \\
\text { safety }\end{array}$} & No & 70 & 5 & 7.14 & 2.5057 & 0.113 \\
\hline & Yes & 28 & 5 & 17.86 & & \\
\hline \multirow[t]{2}{*}{$\begin{array}{l}\text { Type of container used for } \\
\text { handling }\end{array}$} & $\begin{array}{l}\text { Stainless } \\
\text { steel }\end{array}$ & 31 & 3 & 9.68 & 0.0137 & 0.907 \\
\hline & Plastic & 67 & 7 & 10.45 & & \\
\hline
\end{tabular}

\section{Antimicrobial Susceptibility}

In this study, twelve antimicrobial discs were tested against a total of eleven isolates of Listeria monocytogenes for antimicrobial susceptibility test. The isolates showed high resistance to both oxacillin (100\%), amoxicillin (90.91), and ampicillin (72.73\%) whereas the isolates showed $100 \%$ susceptibility against gentamycin and norfloxacin. Of the total 11 isolates subjected for antimicrobial susceptibility test, $11(100 \%)$ exhibited resistance for oxacillin, 10 (90.91\%) for amoxicillin, $9(81.82 \%)$ for vancomycin. Also, 
$8(72.73 \%)$ and $7(63.64 \%)$ of the isolates were susceptible to chloramphenicol and nitrofurantoin (Table $6)$.

Table 6 Results of antimicrobial susceptibility testing of L. monocytogenes isolates $(\mathrm{N}=11)$ from all samples in study towns

\begin{tabular}{|llllllll|}
\hline \multirow{2}{*}{$\begin{array}{l}\text { Antimicrobial } \\
\text { classes }\end{array}$} & Antimicrobials & \multicolumn{2}{l}{ Resistance } & \multicolumn{2}{l}{ Intermediate } & \multicolumn{2}{l|}{ Susceptible } \\
\cline { 2 - 8 } Glycopeptide & Vancomycin & 9 & 81.82 & 1 & 9.09 & 1 & 9.09 \\
\hline Aminoglycosides & Gentamycin & 0 & 0 & 0 & 0 & 11 & 100 \\
\hline Cephem & Cefotaxime & 5 & 45.45 & 3 & 27.27 & 3 & 27.27 \\
\hline B-lactams & Oxacillin & 11 & 100 & 0 & 0 & 0 & 0 \\
\cline { 2 - 8 } & Ampicillin & 8 & 72.73 & 0 & 0 & 3 & 27.27 \\
\cline { 2 - 5 } & Amoxicillin & 10 & 90.91 & 0 & 0 & 1 & 9.09 \\
\hline Quinolones & Nalidixic acid & 6 & 54.55 & 2 & 18.18 & 3 & 27.27 \\
\cline { 2 - 7 } & Norfloxacin & 0 & 0 & 0 & 0 & 11 & 100 \\
\hline Nitrofuran & Nitrofurantoin & 1 & 9.09 & 3 & 27.27 & 7 & 63.64 \\
\hline Macrolide & Azithromycin & 3 & 27.27 & 4 & 36.36 & 4 & 36.36 \\
\hline Phenicol & Chloramphenicol & 3 & 27.27 & 0 & 0 & 8 & 72.73 \\
\hline Tetracycline & Tetracycline & 4 & 36.36 & 0 & 0 & 7 & 63.64 \\
\hline
\end{tabular}

\section{Multi-drug resistance}

The majority of the L. monocytogenes isolates $9(81.82 \%)$ showed MDR. Out of the 9 MDR L. monocytogenes isolates, two isolates showed resistance to 6 classes of drugs (Table 7).

Table 7 Multidrug resistance patterns of L. monocytogenes isolates $(\mathrm{N}=11)$ 


\begin{tabular}{|lll|}
\hline $\begin{array}{l}\text { Antimicrobial resistance pattern } \\
\text { (No of resistant isolates) }\end{array}$ & MDR & Percent of MDR isolates \\
\hline OXC-NAL (1) & 2 & 9.1 \\
\hline VAN-OXC-AMP-AMX (1) & 2 & 9.1 \\
\hline VAN-OXC-AMX-TET (1) & 3 & 9.1 \\
\hline VAN-OXC-AZM-CHL-AMX (1) & 4 & 9.1 \\
\hline VAN-CTX-OXC-AMP-AMX (1) & 3 & 9.1 \\
\hline OXC-AMP-NAL-AZM-AMX (1) & 3 & 9.1 \\
\hline VAN-CTX-OXC-AMP-AZM-AMX (1) & 4 & 9.1 \\
\hline VAN-OXC-AMP-NAL-AMX-TET (1) & 4 & 9.1 \\
\hline VAN-CTX-OXC-AMP-NAL-AMX-TET (1) & 5 & 9.1 \\
\hline VAN-CTX-OXC-AMP-NAL-CHL-AMX-TET (1) & 6 & 9.1 \\
\hline VAN-CTX-OXC-AMP-NAL-NIT-CHL-AMX (1) & 6 & 9.1 \\
\hline
\end{tabular}

OXC, Oxacillin; NAL, Nalidixic acid; VAN, Vancomycin; AMP, Ampicillin; AMX, Amoxicillin; TET, Tetracycline, AZM, Azithromycin; CHL, Chloramphenicol; CTX, Cefotaxime, NIT, Nitrofurantoin; MDR, multidrug resistance

Out of the $L$. monocytogenes isolated from raw milk collected from individual cows ( $N=7), 5(71.43 \%)$ isolates showed MDR and all isolates from bulk tank milk and cottage cheese were MDR (Table 8).

Table 8 Comparison of antimicrobial resistance profile of L. monocytogenes isolated from different sources

\begin{tabular}{|lllllll|}
\hline $\begin{array}{l}\text { Sample } \\
\text { Sources }\end{array}$ & $\begin{array}{l}\text { No. of } \\
\text { L.monocytogenes } \\
\text { isolates }\end{array}$ & $\begin{array}{l}\text { Sensitive } \\
\text { to all } \\
\text { drugs }\end{array}$ & $\begin{array}{l}\text { Intermediate } \\
\text { susceptibility }\end{array}$ & $\begin{array}{l}\text { Resistance } \\
\text { to Single } \\
\text { class of } \\
\text { drug }\end{array}$ & $\begin{array}{l}\text { resistance } \\
\text { to two } \\
\text { classes of } \\
\text { drugs }\end{array}$ & $\begin{array}{l}\text { Multiple } \\
\text { drug } \\
\text { resistance } \\
\text { ( } \geq 3 \\
\text { classes of } \\
\text { drugs) }\end{array}$ \\
\hline Cow & 7 & & & & & \\
\hline BTM & 3 & $0(0.00)$ & $4(57.14)$ & $0(0.00)$ & $2(28.57)$ & $5(71.43)$ \\
\hline CC & 1 & $0(0.00)$ & $2(66.67)$ & $0(0.00)$ & $0(0.00)$ & $3(100)$ \\
\hline Total & 11 & $0(0.00)$ & $0(0.00)$ & $0(0.00)$ & $0(0.00)$ & $1(100)$ \\
\hline
\end{tabular}

BTM, Bulk tank milk; CC, cottage cheese; No., number 


\section{Discussion}

Listeriosis caused by L. monocytogenes is one of the serious foodborne diseases especially for people with a weakened immune system. Milk and milk products are the major sources of L. monocytogenes, which is of great concern for food quality and safety. In food industries, this pathogen can form biofilms that can resist the standard cleaning and disinfection procedures [29]. In the present study, $7.67 \%$ and $2.28 \%$ of milk and milk products are contaminated with Listeria species and L. monocytogenes, respectively. The source of contamination of milk and milk products with Listeria species and $L$. monocytogenes in the present study may be due to udder infection or contaminated feed and feces [30]. The overall prevalence of Listeria species (7.68\%) found in the present study is in accord with the findings of Muhammed et al. [9] who reported a $6.5 \%$ prevalence from milk and milk products. In contrast to the present study, high prevalence of Listeria species in raw milk in Ethiopia such as 25\% [13], 26.6\% in Addis Ababa [31], 22.79\% in Addis Ababa [14], 26.1\% in Addis Ababa [8], 22\% in Selale [8], 20.88\% in DebreBirhan [32] and 14\% in Jimma [9] have been reported previously.

The highest prevalence of $L$. monocytogenes in the present study was found in bulk tank milk $(9.09 \%)$ followed by cottage cheese $(2.85 \%)$ and cow-level raw milk (1.82\%). L. monocytogenes was not isolated from curdling milk perhaps due to the small sample size investigated or better hygienic practice of preparation. In most surveys of raw milk, L. monocytogenes prevalence was detected from 1-16 \% [3336]. In accord with the present isolation rate of L. monocytogenes (2.28\%), Hamdi et al. [37] from Algeria, Aygun and Pehlivanlar [38] from Turkey, and Gebretsadik et al. [8] from Ethiopia reported prevalence of $2.61 \%, 2.2 \%$, and $4 \%$ respectively. As compared to the present finding, Rahimi et al. [4] from Iran and Ning et al. [39] from China reported a lower prevalence of $1.1 \%$ and $0.3-1.2 \%$ respectively. A much higher prevalence of $L$. monocytogenes has also been reported from raw cow milk and milk products from Ethiopia (5.6\%) [14] and Botswana (12.3\%) [27].

Surveys of L. monocytogenes in bulk tank milk from dairy farms in the United States, New Zealand, France, and Belgium showed prevalence ranging from 2.9 to $6.3 \%$ [33, 40-42] which were lower when compared to the current results from bulk tank milk (9.09\%). The present $L$. monocytogenes prevalence from raw milk (1.8\%) is lower when compared to the $4 \%$ reported from Gonder, Ethiopia [13] but similar to the reports of Seyoum et al. [14] who reported $2.04 \%$ prevalence from raw milk of central highlands of Ethiopia.

The prevalence of L. monocytogenes in cottage cheese in the present study (2.85\%) was almost similar with the prevalence reported from various parts of Ethiopia ranging from 0 to $5 \%[8-10,13,31,43,44]$. The heat processing of buttermilk obtained after the churning of sour milk is used to prepare cottage cheese in Ethiopia. The heating practice leads to the precipitation of the protein component of the buttermilk and partly might contribute to the low prevalence of L. monocytogenes in cottage cheese, which even then, might be due to post-processing contamination [14]. Most people in the study towns, and also elsewhere in the country, eat cottage cheese trusting that it is heat processed and safe. However, 
this study demonstrated that this milk product might not be safe unless the public takes precautious measures.

Unlike the previous study by Derra et al. [10] and Gebretsadik et al. [8] who reported a predominant and a high isolation rate of $L$. innocua, $83 \%$, and $60.8 \%$, respectively, no $L$. innocua was isolated from raw milk and milk products in the present study that was similar to the report in Iran [4]. The variations of Listeria species prevalence may be due to differences in risk factors, seasonal variation in milk samples collection, types of samples, or methods of isolation, geographic location, management system, time for conducting the study, level of access to extension service by farmers, and hygienic status of production and processing $[13,14,44-46]$.

Analysis of risk factors at the farm level showed that study town, herd size, farm size, the number of lactating cows, and management system were significantly associated with the prevalence of Listeria species $(p<0.05)$. However, none of these factors turned out tube predictors of the prevalence of Listeria species. The significantly high prevalence of Listeria species at farm level in Holeta town (where most large farms and farms with big herd sizes and lactating cows are found) using univariable logistic regression analysis, might suggest the presence of different risk factors contributing to contamination of milk as compared to Bako town.

The high prevalence of Listeria species in intensively managed milking cows might be related to the risk of fecal contamination of raw milk by Listeria species, which seem to increase during the indoor keeping when the number of fecal excretes, are high since cows are kept together. The effects of the management system on the prevalence Listeria species in housed/indoor cows are higher when compared to outdoor cows, which lead to confinement of the cows and transmission of organism from infected to healthy ones. In an observational epidemiologic study on the occurrence of L. monocytogenes in the feces of dairy cattle, Husu [47] reported that the prevalence of Listeria species in raw milk was associated with the prevalence of the bacteria in fecal samples. Thus, the fecal excretion of $L$. monocytogenes by cattle was the likely source of contamination of raw milk [48].

The challenge of the pathogenic $L$. monocytogenes is not limited to only contamination of food items and the environment, but also being able to resist the most commonly known antimicrobials that are often used for the treatment of infections. Bacterial resistance to antimicrobial drugs has been rising dangerously to high levels over the world, causing serious public health threats [49]. The use of antimicrobial drugs in low-dose or incomplete courses is the main reason for the emergence and spread of antimicrobial drug resistance. On the other hand, the formation of biofilm on foods, instruments, and utensils and the lack of new antimicrobials being developed can also trigger the ability of the organism to resist the activity of antimicrobials [50]. The problem can be higher in Ethiopia since the consumption of raw milk and raw milk products are very widespread. The relatively high level of antimicrobial-resistant $L$. monocytogenes isolates to oxacillin (100\%), amoxicillin (90.91\%), ampicillin (72.72\%), and cefotaxime $(45.45 \%)$ which are commonly prescribed for the treatment of listeriosis in humans is of great concern. The resistance observed to these drugs might be related to the more frequent prescription, relatively 
cheaper price, ease of availability, and accessibility by the local community to fight infections in veterinary and public health sectors $[13,51]$. Furthermore, the situation of antimicrobial resistance is further aggravated by the indiscriminate and extensive usage of antimicrobials in the country. The resistance rate to oxacillin in the present study was similar to the reports of Gomez et al. [52] but higher than reports of leren et al. [53] (94.1\%) and Khen et al. [54] (84.0\%). The level of AMR encountered against nalidixic acid $(54.55 \%)$, tetracycline $(36.36 \%)$, and chloramphenicol $(27.27 \%)$ in the current study was comparable to the results of the previous study [13]. Unlike the present findings, Gebremedhin et al. [55] reported a relatively low level of resistance of $L$. monocytogenes to amoxicillin, cefotaxime, vancomycin (5-15\%). Previously, Gebremedhin et al. [55] reported L. monocytogenes isolates resistant to oxacillin $(80.0 \%)$, nalidixic acid $(70 \%)$, chloramphenicol $(60 \%)$, and tetracycline $(55 \%)$ in the same study area which is higher than the present findings.

Chloramphenicol, gentamycin, and norfloxacin were the most effective antibiotics since $72.74 \%$ to $100 \%$ of the isolates were found to be susceptible. This could be because these drugs were the least frequently used in the study areas in Veterinary services. Thus, no more resistance was developed. A similar suggestion was given by, Calderón-Jaimes et al. [56] in that the development of antimicrobial resistance is nearly always a result of repeated therapeutic use and /or indiscriminate usage. The use and misuse of antimicrobials in farm animal settings as growth promoters or as means of disease treatment have increased antimicrobial resistance among bacteria in their habitat. This reservoir of resistance may be transferred directly or indirectly to humans through food consumption. The resistant bacteria can cause serious health effects directly or through the transmission of antimicrobial-resistance traits to pathogens, causing diseases that are difficult to treat [57].

The high level of resistance (81.82\%) to glycopeptide antibiotic (vancomycin) in the present study needs special consideration and serious monitoring due to the possible spread of genes encoding resistance to vancomycin to methicillin-resistant Staphylococcus aureus (MRSA) strains which are arduous to combat using available therapeutic measures [58]. The presence of a high percentage of MDR L. monocytogenes in milk and milk products, which are often consumed raw in Ethiopia, coupled with the inadequate knowledge of people about foodborne infection, inadequate food safety regulatory system [14], the high number of risky groups for listeriosis, and the peculiar features of listeriosis (cold and hot tolerance, opportunistic, high fatality) suggest that there is a high potential of occurrence and severity of listeriosis in Ethiopia. Thus, integrated hygienic practices from farm to table needs to be implemented to tackle the problem.

\section{Conclusion}

The present findings highlight that milk and milk products in the study areas are contaminated with Listeria spp and the presence of L. monocytogenes and other Listeria species, thus, suggesting inadequate hygienic practices at various levels and potential public health hazards. Study town, herd size, farm size, number of lactating cows and management system were risk factors for the prevalence of Listeria species at farm level, whereas study towns and management system were the significant risk 
factors for isolation of Listeria species at cow level. The L. monocytogenes showed high degree of resistance against Oxacillin, ampicillin, amoxicillin, and vancomycin whereas the isolates were highly susceptibility to gentamycin and norfloxacin. Thus the later two drugs could be considered in the clinical management of sick patients. Listeria monocytogenes isolates showed very high MDR (81.82\%). Avoidance of the consumption of unpasteurized milk, hygienic practices to minimize contamination, rational use and monitoring of antimicrobial drug usage, and further studies consisting of serotyping and molecular studies are suggested.

\section{Declarations}

\section{Ethics approval and consent to participate}

This study was conducted following the Declaration of Helsinki. All study animal owners were informed about the study and informed consents were obtained from all cow owners and individuals participated in this study. Participation in the study was on voluntary bases. Confidentiality was assured by using codes. Ethical clearance was obtained from the Ambo University research and ethical review committee (Date 25/10/2016./Ref. No: ARCEC 004).

\section{Consent for publication}

Not applicable.

\section{Availability of data and materials}

The datasets used and/or analyzed during the current study are available from the corresponding author on reasonable request.

\section{Competing interests}

The authors declare that they have no competing interests.

\section{Funding}

Ambo University financially supported this research work. The funder had no role in the study design and collection, analysis, and interpretation of the data and in writing the manuscript.

\section{Authors' contributions}

All authors made a significant contribution to the work reported either in the conception of the study, study design, execution, acquisition of data, analysis, and interpretation, or in all these areas. Moreover, all authors took part in revising or critically reviewing the article; gave final approval of the version to be published; have agreed on the journal to which the article has been submitted; and agree to be accountable for all aspects of the work. 


\section{Acknowledgments}

We thank Ambo University for funding this research. Many thanks go to the Department of Veterinary Laboratory Technology staff members for their kind and unreserved laboratory assistance. We also appreciate and thank animal owners and animal health assistants of the different district towns for their cooperation during sample collection.

\section{References}

1. Claeys WL, Cardoen S, Daube G, De Block J, Dewettinck K, Dierick K, et al. Raw or heated cow milk consumption: Review of risks and benefits. Food Control. 2013;31(1):251-62.

2. World Health Organization. WHO method sand data sources for the global burden of disease estimate 2000-2011 2013 [Available from: <http://www.who.int/healthinfo/global- burden disease/GlobalCOD-method-2000-2011>..

3. Jami S, Jamshidi A, Khanzadi S. The presence of Listeria monocytogenesin raw milk samples in Mashhad, Iran. Iranian Journal of Veterinary Research. 2010;11(4):363-7.

4. Rahimi E, Ameri M, Momtaz H. Prevalence and antimicrobial resistance of Listeria species isolated from milk and dairy products in Iran. Food Control. 2010;21(11):1448-52.

5. Sahingoz SA, Sahin H. Consumer awareness on food poisoning. Pak J Nutr. 2009;8:1218-23.

6. Gopal N, Hill C, Ross PR, Beresford TP, Fenelon MA, Cotter PD. The Prevalence and Control of Bacillus and Related Spore-Forming Bacteria in the Dairy Industry. Front Microbiol. 2015;6:1418.

7. Sharif L, Al-Malki T. Knowledge, attitude and practice of Taif University students on food poisoning. Food Control. 2010;21(1):55-60.

8. Gebretsadik S, Kassa T, Alemayehu H, Huruy K, Kebede N. Isolation and characterization of Listeria monocytogenes and other Listeria species in foods of animal origin in Addis Ababa, Ethiopia. $\mathrm{J}$ Infect Public Health. 2011;4(1):22-9.

9. Muhammed W, Muleta D, Deneke Y, Gashaw A, Bitew M. Studies on occurence of Listeria monocytogenes and other species in milk and milk products in retail market of Jimma Town, Ethiopia. Asian Journal of Dairying Foods Research. 2013;32(1):35-9.

10. Derra FA, Karlsmose S, Monga DP, Mache A, Svendsen CA, Felix B, et al. Occurrence of Listeria spp. in retail meat and dairy products in the area of Addis Ababa, Ethiopia. Foodborne Pathog Dis. 2013;10(6):577-9.

11. Barancelli GV, Camargo TM, Gagliardi NG, Porto E, Souza RA, Campioni F, et al. Pulsed-Field Gel Electrophoresis characterization of Listeria monocytogenes isolates from cheese manufacturing plants in São Paulo, Brazil. Int J Food Microbiol. 2014;173:21-9.

12. Stessl B, Fricker M, Fox E, Karpiskova R, Demnerova K, Jordan K, et al. Collaborative survey on the colonization of different types of cheese-processing facilities with Listeria monocytogenes. Foodborne Pathog Dis. 2014;11(1):8-14. 
13. Garedew L, Taddese A, Biru T, Nigatu S, Kebede E, Ejo M, et al. Prevalence and antimicrobial susceptibility profile of Listeria species from ready-to-eat foods of animal origin in Gondar Town, Ethiopia. BMC Microbiol. 2015;15:100.

14. Seyoum ET, Woldetsadik DA, Mekonen TK, Gezahegn HA, Gebreyes WA. Prevalence of Listeria monocytogenes in raw bovine milk and milk products from central highlands of Ethiopia. $J$ Infect Dev Ctries. 2015;9(11):1204-9.

15. Odu N, Okonko I. Prevalence and antibiotic susceptibility of Listeria monocytogenes in retailed meats in port harcourt metropolis, Nigeria. J Journal of Public Health Research. 2017;7(4):91-9.

16. Rodrigues CS. Sá CVGCd, Melo CBd. An overview of Listeria monocytogenes contamination in ready to eat meat, dairy and fishery foods. Ciência Rural. 2016;47.

17. World Health Organization. Foodborne disease outbreaks. Guidelines for investigation: WHO Press; 2008.

18. CSA. Population and Housing Census of Ethiopia, Addis Ababa, Ethiopia. 2007.

19. Ambo Woreda Livestock and Fishery Resource Development Office. Livestock Population Reports. In: desks Api, editor.; 2019.

20. Holeta woreda livestock and fishery resource development office. Livestock Population Reports. In: desks Api, editor. 2019.

21. Bako Tibe Woreda Livestock and Fishery Resource Development Office. Livestock Population Reports. In: desks Api, editor:; 2019.

22. Thrusfield M. Veterinary Epidemiology: Describing disease occurrence. 3rd Edition ed: Blackwell Publishing; 2007. 46-74 p.

23. International organization for standardization. Microbiology of food and animal feeding stuffs Horizontal method for the detection and enumeration of Listeria monocytogenes Part 1: Detection method. Geneva, Switzerland.2004.

24. Kiiyukia C. Laboratory manual of food microbiology for Ethiopian health and nutrition research institute. UNIDO project (YA/ETH/03/436/11-52). 2003:1-197.

25. European Commission. The certification of the number fraction of negative capsules and the mean number of colony-forming particles of Listeria monocytogenes in one capsule containing artificially contaminated milk powder. 1996. p. 1-112.

26. CLSI. Performance Standards for antimicrobial susceptibility testing; fifteenth informational supplement, M100_S15, Vol 25. 2005.

27. Morobe I, Obi CL, Nyila MA, Gashe B, Matsheka M. Prevalence, antimicrobial resistance profiles of Listeria monocytognes from various foods in Gaborone, Botswana. African Journal of Biotechnology. 2009;8(22).

28. Dohoo I, Martin W, Stryhn H. Veterinary Epidemiologic Research. 2nd Edition ed. Canada: AVC Inc.; 2009. 
29. Centorame P, D'Angelo AR, Simone FD, Salini R, Cornacchia A, Marrone R, et al. Listeria monocytogenes biofilm production on food packaging materials submitted to physical treatment. Ital J Food Saf. 2017;6(3):6654.

30. Bourry A, Poutrel B, Rocourt J. Bovine mastitis caused by Listeria monocytogenes: characteristics of natural and experimental infections. Journal of medical microbiology. 1995;43(2):125-32.

31. Mengesha D, Zewde BM, Toquin MT, Kleer J, Hildebrandt G, Gebreyes WA. Occurrence and distribution of Listeria monocytogenes and other Listeria species in ready-to-eat and raw meat products. Berl Munch Tierarztl Wochenschr. 2009;122(1-2):20-4.

32. Girma Y, Abebe B. Isolation, identification and antimicrobial susceptibility of Listeria species from raw bovine milk in Debre-Birhan Town, Ethiopia. Journal of Zoonotic Diseases Public Health. 2018;2(1):4.

33. Van Kessel JA, Karns JS, Lombard JE, Kopral CA. Prevalence of Salmonella enterica, Listeria monocytogenes, and Escherichia coli virulence factors in bulk tank milk and in-line filters from U.S. dairies. J Food Prot. 2011;74(5):759-68.

34. Fox EM, Leonard N, Jordan K. Molecular diversity of Listeria monocytogenes isolated from Irish dairy farms. Foodborne Pathog Dis. 2011;8(5):635-41.

35. Mohammed HO, Stipetic K, McDonough PL, Gonzalez RN, Nydam DV, Atwill ER. Identification of potential on-farm sources of Listeria monocytogenes in herds of dairy cattle. Am J Vet Res. 2009;70(3):383-8.

36. Ryser TE. Incidence and behavior of Listeria monocytogenes in unfermented dairy products. In: Ryser ME, editor. Listeria, Listeriosis, and food safety. USA: CRC Press; 2007. pp. 357-403.

37. Hamdi TM, Naïm M, Martin P, Jacquet C. Identification and molecular characterization of Listeria monocytogenes isolated in raw milk in the region of Algiers (Algeria). Int J Food Microbiol. 2007;116(1):190-3.

38. Aygun 0 , Pehlivanlar S. Listeria spp. in the raw milk and dairy products in Antakya, Turkey. Food Control. 2006;17(8):676-9.

39. Ning P, Guo K, Cheng L, Xu L, Zhang C, Cui H, et al. Pilot survey of raw whole milk in China for Listeria monocytogenes using PCR. Food Control. 2013;31(1):176-9.

40. Desmasures N, Bazin F, Guéguen M. Microbiological composition of raw milk from selected farms in the Camembert region of Normandy. J Appl Microbiol. 1997;83(1):53-8.

41. Marshall JC, Soboleva TK, Jamieson P, French NP. Estimating Bacterial Pathogen Levels in New Zealand Bulk Tank Milk. J Food Prot. 2016;79(5):771-80.

42. De Reu K, Grijspeerdt K, Herman L. A Belgian survey of hygiene indicator bacteria and pathogenic bacteria in raw milk and direct marketing of raw milk farm products. J Food Saf. 2004;24(1):17-36.

43. Molla B, Yilma R, Alemayehu D. Listeria monocytogenes and other Listeria species in retail meat and milk products in Addis Ababa, Ethiopia. Ethiopian Journal of Health Development. 2004;18(3):20812. 
44. Teshome Y, Giragn F, Gudeta D, Desa G, Bekele D. Isolation and Prevalence of Listeria Species in Milk and Milk Product samples Collected from Bishoftu and Dukemtowns, Oromia, Ethiopia. World Journal of Dairy Food Sciences. 2019;14(2):196-201.

45. Cerva C, Bremm C, Reis EM, Bezerra AV, Loiko MR, Cruz CE, et al. Food safety in raw milk production: risk factors associated to bacterial DNA contamination. Trop Anim Health Prod. 2014;46(5):877-82.

46. Oliver SP, Jayarao BM, Almeida RA. Foodborne pathogens in milk and the dairy farm environment: food safety and public health implications. Foodborne Pathog Dis. 2005;2(2):115-29.

47. Husu JR. Epidemiological studies on the occurrence of Listeria monocytogenes in the feces of dairy cattle. Zentralbl Veterinarmed B. 1990;37(4):276-82.

48. Ivanek R, Gröhn YT, Wiedmann M. Listeria monocytogenes in multiple habitats and host populations: review of available data for mathematical modeling. Foodborne Pathog Dis. 2006;3(4):319-36.

49. World Health Organization. Listeriosis 2018 [Available from: https://www.who.int/news-room/factsheets/detail/listeriosis.

50. Cepas V, López Y, Muñoz E, Rolo D, Ardanuy C, Martí S, et al. Relationship Between Biofilm Formation and Antimicrobial Resistance in Gram-Negative Bacteria. Microb Drug Resist. 2019;25(1):72-9.

51. Al-Ashmawy MA, Gwida MM, Abdelgalil KH. Prevalence. Detection Methods and Antimicrobial Susceptibility of Listeria monocytogenes Isolated from Milk and Soft Cheeses and its Zoonotic Importance. World Appl Sci J. 2014;29:869-78.

52. Gomez D, Azon E, Marco N, Carraminana JJ, Rota C, Arino A, et al. Antimicrobial resistance of Listeria monocytogenes and Listeria innocua from meat products and meat-processing environment. Food Microbiol. 2014;42:61-5.

53. Ieren II, Bello M, Kwaga JKP. Occurrence and antibiotic resistance profile of Listeria monocytogenes in salad vegetables and vegetable salads sold in Zaria, Nigeria. Afr J Food Sci. 2013;7(9):334-8.

54. Khen BK, Lynch OA, Carroll J, McDowell DA, Duffy G. Occurrence, antibiotic resistance and molecular characterization of Listeria monocytogenes in the beef chain in the Republic of Ireland. Zoonoses Public Health. 2015;62(1):11-7.

55. Gebremedhin EZ, Hirpa G, Borana BM, Sarba EJ, Marami LM, Kelbesa KA, et al. Listeria Species Occurrence and Associated Factors and Antibiogram of Listeria monocytogenes in Beef at Abattoirs, Butchers, and Restaurants in Ambo and Holeta in Ethiopia. Infect Drug Resist. 2021;14:1493-504.

56. Calderón-Jaimes E, Espinosa de los Monteros LE, Avila-Beltrán R. Epidemiology of drug resistance: the case of Staphylococcus aureus and coagulase-negative staphylococci infections. Salud Publica Mex. 2002;44(2):108-12.

57. Economou V, Gousia P. Agriculture and food animals as a source of antimicrobial-resistant bacteria. Infect Drug Resist. 2015;8:49-61.

58. Chambers HF. Methicillin-resistant staphylococci. Clin Microbiol Rev. 1988;1(2):173-86. 